\title{
Metallothionein and metal levels in flounder Platichthys flesus from four field sites and in flounder dosed with water-borne copper
}

\author{
J. Overnell ${ }^{1, *}$, M. I. Abdullah ${ }^{2}$ \\ ${ }^{1}$ NERC Institute of Marine Biochemistry, St. Fittick's Road, Aberdeen, AB1 3RA, Scotland, United Kingdom \\ ${ }^{2}$ Department of Marine Zoology and Marine Chemistry, Biology Institute, University of Oslo, PO Box 1064, N-0316 Blindern, \\ Oslo 3, Norway
}

\begin{abstract}
Concentrations of metallothionein (MT) and of zinc, copper, iron, manganese, cadmium and lead were measured at the GEEP Workshop in liver and kidney of flounder Platichthys flesus from 4 sites in Langesundfjord, Norway, subject to a pollution gradient, and from 4 mesocosm basins dosed with varying levels of copper and diesel oil. Little difference was found between MT levels in samples from the 3 polluted field sites, though kidney MT levels were significantly higher than at the field reference site. Tissue zinc levels were highest in the most heavily polluted fjord site but there was no correlation between hepatic MT and total hepatic zinc. Copper in the mesocosm basins was not accumulated in the flounder livers, nor was liver or kidney MT elevated by the treatment.
\end{abstract}

\section{INTRODUCTION}

Metallothionein (MT) is a low molecular weight, heatstable, metal-binding, intracellular protein isolated from various animals. It appears to be ubiquitous in vertebrate tissues, and in mammals is readily inducible by a variety of agents, including copper, cadmium and zinc to which it binds (Kägi \& Nordberg 1979, Karin 1985). Several species of freshwater fish respond to metals by synthesizing MT. Roch et al. (1982) found a good correlation between hepatic MT levels in rainbow trout caught downstream from a copper mine, and the copper level in the ambient water. Thomas et al. (1985) and Kay et al. (1986) report that trout, roach and stone loach all showed enhanced levels of MT in response to water-borne zinc and cadmium. However, they found that trout exposed to cadmium alone sequestered the cadmium in the liver as a low molecular weight nonmetallothionein cadmium binding protein. In mammals, various non-metal agents, mostly associated with stress (including noise, injury, bacterial infection and interleukin 1, liver damage and corticosteroid hormones) also induce MT synthesis (Karin 1985).

\footnotetext{
- Present address: Scottish Marine Biological Association, Dunstaffnage Marine Research Laboratory, PO Box 3, Oban, Argyll PA34 4AD, Scotland, United Kingdom
}

To assess the potential of $\mathrm{MT}$ in marine fish as an indicator of sub-lethal biological effects of metal pollution, we need basic information about its induction. We must know the rates of MT induction and of degradation, the natural seasonal variation in endogenous $\mathrm{MT}$, the specificity of MT induction to metal exposure and its response to different routes of exposure, and the MT response to non-metallic potential MT inducers.

Overnell et al. (1987a) have shown that in plaice Pleuronectes platessa the synthesis of MT following zinc injections was rapid (within 1 wk) whereas degradation was slow (half-life ca $30 \mathrm{~d}$ ). They could not detect increased levels of liver MT following administration of cortisol, dexamethasone, endotoxin or turpentine at concentrations which would have been expected to induce MT in mammals. During the spawning season female plaice showed highly variable liver MT with some very high values associated with the early stages of maturation (Overnell et al. 1987b), indicating that spawning females should be avoided for monitoring purposes. Olsson et al. (1986) also report elevated levels of liver MT in cultured female rainbow trout during the spawning season.

The relative importance of water-borne and dietary routes of metal intake on metal levels (and hence possibly MT levels) in fish has been studied by several research groups. O'Grady \& Abdullah (1985) found that 
uptake of zinc into liver and kidney of brown trout occurred only when the fish were feeding, suggesting that the dietary route was the more important. Dallinger \& Kautzky (1985) strongly suggest that under environmental conditions the dietary route is the more important for copper uptake by rainbow trout.

We have tried to evaluate the usefulness of MT as an indicator of metal pollution by correlating the degree of metal contamination (determined by tissue metal concentrations) with the levels of hepatic and renal MT.

\section{MATERIAL AND METHODS}

Sampling of tissue. The Platichthys flesus examined were outside their breeding season and none of the females sampled had developed or developing gonads. Flounder were sampled from 4 sites (1 to 4$)$ in Langesundfjord, Norway, and taken from the 4 mesocosm basins ( $\mathrm{C}$ : control, L: low, $\mathrm{M}$ : medium, $\mathrm{H}$ : high doses of copper and diesel oil, over 4 mo exposures; nominal water concentrations of $\mathrm{Cu}$ were $\mathrm{L}: 0.8 \mu \mathrm{g} \mathrm{l}^{-1}$, M: $5 \mu \mathrm{g} \mathrm{l}^{-1}, \mathrm{H}: 20 \mu \mathrm{g} \mathrm{l}^{-1}$ ). For details of sites and exposures see Bakke et al. (1988) and Follum \& Moe (1988).

Flounder were transported to the laboratory and killed by a blow on the head. Liver and kidney were removed and samples (ca $1 \mathrm{~g}$ ) taken for metal and MT analysis. Samples for MT analysis were homogenised in $10 \mathrm{mM}$ Tris $\mathrm{HCl}(1: 4, \mathrm{w}: \mathrm{v})$ and stored at $-70^{\circ} \mathrm{C}$ until required. Samples for metal analysis were frozen and freeze dried.

Metallothionein determinations. MT was analysed by the cadmium saturation assay of Eaton \& Toal (1983), slightly modified. In this assay the sample is equilibrated with ${ }^{109} \mathrm{Cd}$ of known specific activity. Weakly bound cadmium is removed by addition of a large excess of haemoglobin which is sedimented after heat denaturation. The remaining radioactivity is due to cadmium bound to MT.

It had been found earlier (Overnell et al. 1987a) that, using this assay for fish tissue, small quantities of MT in samples tended to give erroneously low MT values and, using large quantities, there was the risk of exceeding the upper limit of the assay. Therefore the following procedure was used: for each assay 3 samples of supernatant from the heat-treated cytosol were taken (5,10 and $15 \mu \mathrm{l}$ for liver; 50,100 and $150 \mu \mathrm{I}$ for kidney), immediately incubated with ${ }^{109} \mathrm{Cd}$ and then treated with haemoglobin freshly prepared from flounder blood, by haemolysis of erythrocytes, and stored at $-20^{\circ} \mathrm{C}$. The highest MT estimate was used in data analysis.

Metal determinations. Freeze dried tissue samples were weighed and transferred to acid washed conical flasks. Redistilled nitric acid ( $15 \mathrm{ml}$ ) was added and the samples heated under reflux on a $120^{\circ} \mathrm{C}$ hotplate. When the samples were clear and colourless, mineralization was judged to be complete and samples were evaporated to dryness. Residues were dissolved in $6 \mathrm{~N}$ $\mathrm{HCl}(1 \mathrm{ml})$ and made up to 10 or $25 \mathrm{ml}$ with distilled water. Metal concentrations were determined by atomic absorption spectrophotometry in a Varian AA6 instrument using standards in $0.1 \mathrm{~N} \mathrm{HCl}$.

Analysis of data. Data were analysed by 1-way analysis of variance and means compared for significant differences, at the $p<0.05$ level, using Tukey's multiple comparison method (Scheffé 1959).

\section{RESULTS AND DISCUSSION}

\section{Field samples}

The MT assay appeared applicable to Platichthys flesus liver tissue, since the calculated MT concentrations were independent of sample volume. This was not true for kidney tissue, where MT concentrations increased with sample volume. However, although absolute values may be in doubt, the values (Fig. 1) were all based on the same sample size $(150 \mu \mathrm{l})$ and thus are inter-comparable.

Mean hepatic MT values did not differ significantly between sites, but kidney MT concentrations in flounder from Site 1, the reference site, were significantly lower than from other sites. Since the endogenous levels of flounder kidney MT are so much lower than

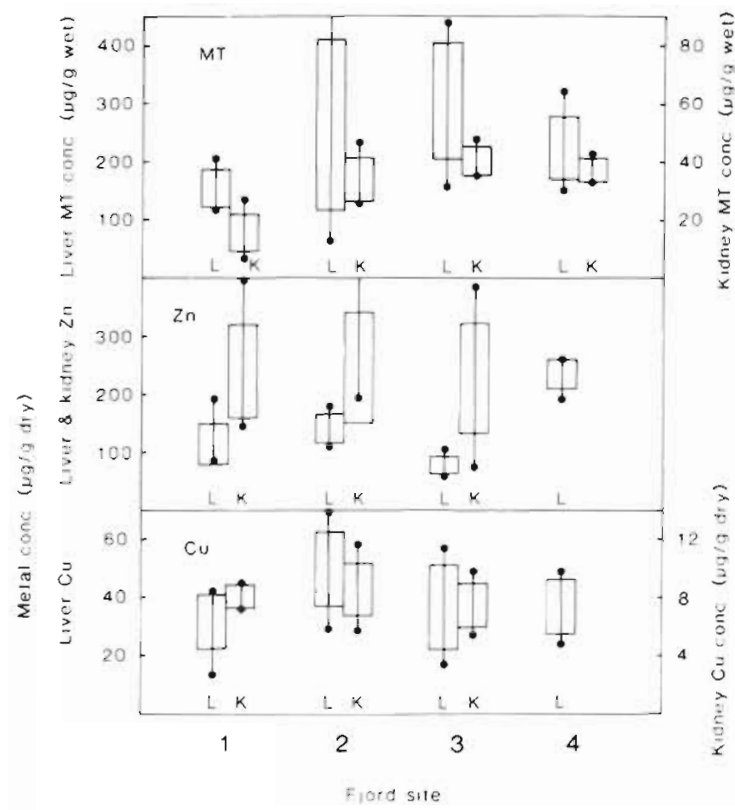

Fig. 1. Platichthys flesus. Metallothionein, zinc and copper concentrations in livers $(L)$ and kidneys $(K)$ of flounder from Langesundfjord sites 1 to 4 . Boxes: 1 SD either side of means $(n=6 \text { to } 8)_{i}$ outlier points are maximum and minimum values 
Table 1. Platichthys flesus. Concentrations of metals ( $\mu \mathrm{g} \mathrm{g}^{-1} \mathrm{dry} w \mathrm{w}$ ) in liver and kidney in individuals from 4 field sites in Langesundfjord, and 4 basins in the mesocosm experiment ( $C$ : control, L: low, $M$ : medium, H: high copper dosing; nominal water Cu concentrations of $0.8,5$ and $20 \mu \mathrm{g}^{-1}$ for $\mathrm{L}, \mathrm{M}$ and H basins). Means $\pm \mathrm{SD}$; for Cu and Zn concentrations in liver and kidney see Fig. 1.

\begin{tabular}{|c|c|c|c|c|c|c|c|c|c|}
\hline Source & $n$ & Liver Fe & Kidney Fe & Liver Mn & Kidney Mn & Liver $\mathrm{Cd}$ & Kidney Cd & Liver $\mathrm{Pb}$ & Kidney $\mathrm{Pb}$ \\
\hline \multicolumn{10}{|l|}{ Site } \\
\hline 1 & 6 & $247 \pm 93$ & $692 \pm 129$ & $2.4 \pm 0.8$ & $2.9 \pm 0.8$ & $0.5 \pm 0.2$ & $0.6 \pm 0.1$ & $0.7 \pm 0.4$ & $2.1 \pm 0.5$ \\
\hline 2 & 8 & $411 \pm 152^{\circ}$ & $630 \pm 242$ & $3.6 \pm 2.1$ & $4.3 \pm 0.9$ & $1.1 \pm 1.0$ & $0.9 \pm 0.4$ & $4.3 \pm 4.1^{\circ}$ & $4.4 \pm 2.9$ \\
\hline 3 & 8 & $154 \pm 79$ & $481 \pm 112$ & $2.1 \pm 0.4$ & $4.7 \pm 1.1^{\circ}$ & $0.3 \pm 0.1$ & $0.7 \pm 0.2$ & $1.3 \pm 0.2$ & $5.5 \pm 1.8^{\circ}$ \\
\hline 4 & 4 & $223 \pm 94$ & $--^{a}$ & $2.4 \pm 0.4$ & - & $0.7 \pm 0.3$ & - & $5.0 \pm 0.5^{\circ}$ & - \\
\hline \multicolumn{10}{|l|}{ Basin } \\
\hline $\mathrm{C}$ & 4 & $527 \pm 153$ & - & $3.2 \pm 2.5$ & - & $1.1 \pm 0.5$ & - & $7.9 \pm 4.2$ & - \\
\hline $\mathrm{L}$ & 4 & $310 \pm 36$ & - & $2.9 \pm 0.9$ & - & $0.8 \pm 0.2$ & - & $8.3 \pm 5.4$ & - \\
\hline M & 4 & $826 \pm 794$ & - & $7.6 \pm 9.8$ & - & $1.7 \pm 1.3$ & - & $8.3 \pm 4.3$ & - \\
\hline $\mathrm{H}$ & 4 & $328 \pm 206$ & - & $3.1 \pm 1.2$ & - & $0.8 \pm 0.3$ & - & $6.2 \pm 1.8$ & - \\
\hline
\end{tabular}

the hepatic levels, kidney MT may be a more sensitive measure of metal contamination in this species. However, there is considerable species variation in such measurements: in turbot, kidney MT levels are higher than those of liver (Overnell et al. unpubl.). Thus, other studies are required to confirm the inference from kidney MT values of a significant metal contaminant effect at Sites 2, 3 and 4 .

Table 1 lists analyses of iron, manganese, cadmium and lead in flounder liver and kidney; zinc and copper data are presented in Fig. 1. Liver lead levels at Sites 2 and 4 were significantly higher than at the reference site (1). Copper levels were not significantly different between sites. However, hepatic zinc levels were substantially (and significantly) higher in flounder from Site 4 . These results for zinc and copper may be com-

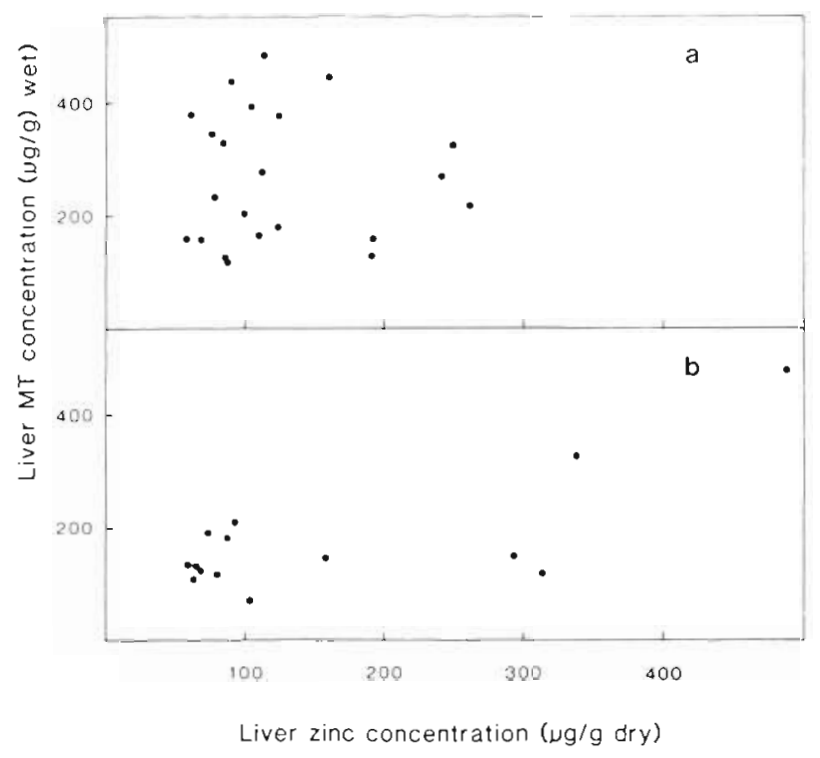

Fig. 2. Platichthys flesus. Hepatic metallothionein values plotted against total zinc concentration, for individual flounder from (a) fjord sites, (b) mesocosm basins pared with those of Bryan \& Gibbs (1983) who found similar hepatic zinc levels in flounder from a copper contaminated estuary and from a clean estuary (203 and $190 \mu \mathrm{g} \mathrm{g}^{-1}$ dry wt), but elevated hepatic copper levels in fish from the copper-contaminated estuary compared with the clean one (118 and $60 \mathrm{\mu g} \mathrm{g}^{-1}$ dry wt). If the hepatic zinc and copper levels in the sites sampled here reflect metal input, an input to the fjord from zinc but not copper is indicated.

Overnell et al. (1987a, b) found good correlations between liver zinc and liver MT values in plaice. However, a plot of MT concentration versus total zinc shows little or no correlation (Fig. 2a). This is puzzling and as yet unexplained.

\section{Mesocosm samples}

Mesocosms were stocked with flounder from what was believed to be a relatively unimpacted area of Oslofjord, in the vicinity of the Solbergstrand experimental facility, and the water to which they were exposed was taken from a depth of $40 \mathrm{~m}$ in the same part of the fjord. However, analysis of hepatic metal levels in the mesocosm fish (Table 1; Fig. 3) showed some unexpected results. Values for lead in control flounder (and also in treated individuals) were higher than in any of the flounder from the Langesundfjord sites, including the most contaminated one. Hepatic copper levels in all copper-dosed flounder were no higher than in controls (except for 1 individual in the medium-dose basin with a liver copper concentration of $102 \mu \mathrm{g} \mathrm{g}^{-1}$ ).

Both hepatic and renal MT concentrations were remarkably constant, the basins showing no significant differences from each other (Fig. 3). Hepatic MT concentrations were somewhat lower than those in floun- 


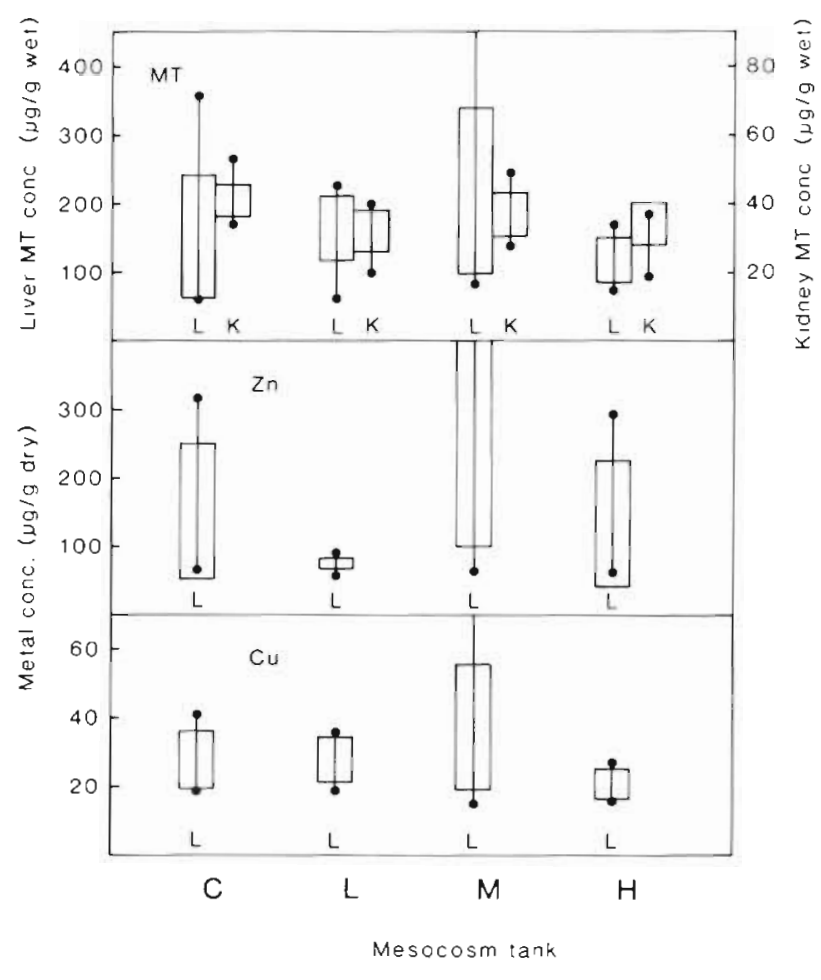

Fig. 3. Platichthys flesus. Metallothionein, zinc and copper concentrations in liver $(L)$ and kidneys $(K)$ of flounder experimentally exposed to copper in mesocosm basins (C: control, $L$ : low, M: medium, H: high dose). Values expressed as in Fig. 1

der from the reference site. There was again no correlation between liver MT and total liver zinc (Fig, 2b). Renal MT values (including those from the control basin) were higher than those in flounder from the reference site and equivalent to those from the polluted sites. Comparisons of mesocosm flounder with those freshly caught from the fjord are difficult, since the mesocosm fish were in a poorer 'general condition', Livers contained less storage lipid than those of the freshly caught fjord fish and the fish were clearly less well fed. Starvation in mammals increases hepatic MT (Bremner \& Davies 1975). In addition, the effect of the concomitant treatment with diesel oil is difficult to evaluate.

\section{CONCLUSIONS}

Metal analysis of Platichthys flesus livers from the Langesundfjord sites showed significantly greater zinc concentrations at the most polluted site. This was not reflected in elevated $\mathrm{MT}$ concentrations, suggesting that this metal exposure was not harmful.

Flounders did not accumulate copper in their livers nor did they show elevated hepatic or renal MT when exposed to up to $20 \mathrm{ppb}$ ionic copper for $4 \mathrm{mo}$, again suggesting that this exposure was not harmful.

Acknowledgement. The authors thank Ms I. Rosvik for technical assistance.

\section{LITERATURE CITED}

Bakke, T., Follum, O. A., Moe, K. A., Serensen, K. (1988). The GEEP Workshop: mesocosm exposures. Mar. Ecol. Prog Ser. 46: 13-18

Bremner, I., Davies, N. T (1975). The induction of metallothionein in rat liver by zinc injection and restriction of food intake. Biochem. J. 149: 733-738

Bryan, G. W., Gibbs, P. E. (1983). Heavy metals in the Fal estuary, Cornwall: a study of long-term contamination by mining waste and its effects on estuarine organisms. Mar Biol. Ass. U.K. Occ. Publ. No. 2

Dallinger, R., Kautzky, H. (1985). The importance of contaminated food for the uptake of heavy metals by rainbow trout (Salmo gairdneri): a field study. Oecologia (Berl.) 67. $82-89$

Eaton, D. L., Toal, B. F. (1983). A simplified method for quantitating metallothionein in biological tissue. Sci. Total Environ. 28: 375-384

Follum, O. A. Moe, K. A. (1988). The GEEP Workshop: field sampling. Mar. Ecol. Prog. Ser. 46: 7-12

Kägi, J. H. R. Nordberg. M. (1979). Metallothionein. Experientia 34 (Suppl.)

Karin, M. (1985). Metallothioneins: proteins in search of function. Cell $41 \cdot 9-10$

Kay, J., Brown, M. W., Cryer, A., Solbé, J. F. de L. G., Shurben, D., Garvey, J. S., Thomas, D. G. (1987). Metallothionein gene expression and cadmium toxicity in freshwater fish In: Kägi, J H. R. (ed.) Metallothionein. II. Experientia 52 (Suppl.): $627-630$

O'Grady, K. T., Abdullah, M. I. (1985). Mobility and residence of zinc in brown trout Salmo trutta: Results of environmentally induced change through transfer. Environ. Pollut. Ser A 38: 109-127

Olsson, P.-E., Haux, C., Förlin, L. (1986). Variations in hepatic metallothionein, zinc and copper levels during an annual reproductive cycle in rainbow trout, Salmo gairdneri. Fish Physiol. Biochem. 3: 39-47

Overnell, J., McIntosh, R., Fletcher, T C. (1987a). The enhanced induction by zinc of zinc metallothionein and its half-life in the marine fish Pleuronectes platessa, and the influence of stress factors on metallothionein levels. Experientia 43: 178-181.

Overnell, J., McIntosh, R., Fletcher, T C (1987b). The levels of liver metallothionein and zinc in the fish, plaice (Pleuronectes platessa L), during the breeding season and the effect of oestradiol injection. J. Fish. B1ol. 30: 539-546

Roch, M., McCarter, J. A., Matheson, A. T., Clark, M. J. R. Olafson, R.W (1982). Hepatic metallothionein in rainbow trout (Salmo gairdneri) as an indicator of metal pollution in the Campbell river system. Can. J. Fish. Aquat. Sci. 39 $1596-1601$

Scheffé, H. (1959). The analysis of varlance. Wiley, New York Thomas, D. G., Brown, M. W., Shurben, D., Solbé, J. F de I. G., Cryer, A., Kay, J. (1985). A comparison of the sequestration of cadmium and zinc in the tissues of rainbow trout (Salmo gairdneri) following exposure to the metals singly or in combination. Comp. B1ochem. Physiol. 82C: 55-62 